\title{
Association of Ki-67 Expression and the Aggressiveness of Hepatocellular Carcinoma
}

\author{
WALAA G. EL-GENDY, M.Sc.*; NANIS S. HOLAH, M.D.**; DALIA R. EL-SHARAKY, M.D.**; \\ DINA S. EL-AZAB, M.D.*; ASMAA G. ABDOU, M.D.** and MOHAMMED T. BADR, M.D.* \\ The Department of Pathology, National Liver Institute* and Faculty of Medicine ${ }^{* *}$, Menoufia University, Shebin El-Kom, Egypt
}

\begin{abstract}
Background: Ki-67 is a nuclear proliferative marker. It is therefore widely used as a cell proliferation marker to grade tumors.

Aim of Study: The aim of the current study was to assess the possible association between $\mathrm{Ki}-67$ and the aggressiveness of hepatocellular carcinoma.
\end{abstract}

Material and Methods: This study was conducted at Pathology Department in National Liver Institute, Menoufia University. A total of 114 cases were included. TMA was performed for tumor blocks and stained with antibody against Ki-67.

Results: The percentage of Ki-67 expression ranged between 1 and $95 \%$ with a mean \pm SD of $56.72 \pm 40.53$ and a median of 80 . As regard Ki-67 expression, large tumor size group were significantly associated with increased expression of Ki-67 ( $p=0.049)$. On the other hand, older age group $(>60$ years) and large tumor size group $(>5 \mathrm{~cm})$ were significantly associated with increased percentage of Ki-67 expression $(p=0.035$ and 0.015$)$ respectively.

Conclusion: Ki-67 expression is associated with aggressive hepatocellular carcinoma, so it could change the type of therapy for these tumors.

Key Words: Ki-67 - Hepatocellular carcinoma-Aggressiveness - TMA - Expression.

\section{Introduction}

HEPATOCELLULAR Carcinoma (HCC) is the sixth most common malignancy and is the leading cause of mortality in patients with cirrhosis $[1,2]$ An estimated half million new cases are diagnosed each year world-wide with disease burden highest in developing countries (85\% of all cases) [3,4].

The average age of diagnosis is 65 years with a shift in the last decade toward diagnosis at an

Correspondence to: Dr. Walaa El-Gendy, E-Mail: drwalaaelgendy@yahoo.com earlier age $[\mathbf{1 , 4}]$. This trend is especially seen in developing countries and has implications for treatment $[\mathbf{1 , 4}]$.

Chronic HBV and HCV infections are the major risk factors for the development of HCC through a multistep pathway that involves viral and nonviral dependent pathophysiological steps [5]. Inflammation, necrosis, fibrosis, and ongoing regeneration characterize the cirrhotic liver and contribute to $\mathrm{HCC}$ development especially in patients with Hepatitis C Virus (HCV) [6].

$\mathrm{Ki}-67$ is a nuclear DNA-binding protein with two human isoforms that have predicted molecular weights of $320 \mathrm{kDa}$ and $359 \mathrm{kDa}[7,8]$. It is a cell proliferation antigen that is constitutively expressed in cycling mammalian cells [9]. A detailed cell cycle analysis showed that the Ki-67 antigen is expressed in cells at G1, S and G2-M phases but not in G0 phase of the cell cycle [10]

The dynamic localization of Ki-67 has led to suggestions that it could coordinate nucleolar disassembly and reassembly at either side of mitosis [11]. Indeed, Ki-67 is required to localize nucleolar granular components to mitotic chromosomes, so it may play a role in nucleolar segregation between daughter cells [12].

Studies showed that the proliferative activity of a wide variety of tumors may be of prognostic value with respect to survival of the patient. Current methods of assessing the proliferation and growth of tumors including immunohistochemical staining of $\mathrm{Ki}-67$ [13]

Immunostaining of $\mathrm{Ki}-67$ is a quick, simple and sensitive technique for the estimation of proliferative activity of tumors and it serves as one of the major factors related to tumor proliferation 
that can be assessed with Immunohistochemistry (IHC) [14]

\section{Material and Methods}

This retrospective study was carried out on 114 liver biopsies obtained from patients who underwent partial or total hepatectomy for HCC.

Paraffin embedded blocks of those specimens were retrieved from the Archive of Pathology Department, National Liver Institute, Menoufia University, in the period between 2010 and 2017.

Clinical data were retrieved from medical files preserved at the Archive of Surgery Department and Oncology Unit, National Liver Institute, Menoufia University.

All patients included in the study were completely evaluated by clinical, laboratory and radiological data collected from patients' medical records:

Clinical data included patient age and gender.

Laboratory investigations included virology state and alpha fetoprotein level.

Radiological data included number, size (in greatest dimension) and site of focal lesions.

Hi stop athological evaluation included histopathological type, tumor grade, degree of differentiation, adjacent liver and pathologic stage (According to AJCC staging system, 7 th edition).

\section{Tissue microarray construction (TMA):}

Hematoxylin and Eosin (H \& E) stained slides were used to identify viable and representative areas of each sample that is circled with a pilot pen.

Tissue cores with a diameter of 1.5 micron from predefined regions of each specimen in the donor paraffin block were punched manually using a tissue array needle set we utilized the TMA needles with a simple handheld holder with a great success without the need to use the expensive tissue arrayer instrument [15], and arrayed in triplicate on a recipient paraffin block, into a ready-made hole, guided by a defined $\mathrm{x}-\mathrm{y}$ position. A control normal tissue is placed in a strategic regions throughout the blocks or asymmetrically at one end of the block.

Tissue Microarray (TMA) construction map is created, indicating the position and origin of each core in the tissue microarray. The map is then used to set up the actual construction of the array. The
TMA is divided into different rows designated by capital letters. These quadrants are further separated in a checkerboard order by letters and numbers [16]

\section{Immunohistochemical staining:}

About 4 micron thick sections of these tissue array blocks were cut and mounted on positive charged slides and used for immunohistochemical staining by Ki-67 which was a concentrated rabbit monoclonal antibody (Mab-Mib-1-YLEM, Dako Cytomation, Glostrup, Denmark). The primary antibody was added at a 1:50 dilution. The detection Kit was Invitrogen (Cell marque, USA). In this system, two reagents were utilized; the biotinlated secondary anti-immunoglobulin which is a purified goat polyvalent anti-mouse IgG capable of binding to the primary antibody and the streptvidin-biotin enzyme complex.

Positive controls for the reaction were performed with specific paraffin embedded sections of lymph node and negative controls were made by substituting the primary antibody with nonimmune serum.

Finally, the reaction can be visualized by appropriate substrate/chromogen (Diaminobenzidine, $\mathrm{DAB}$ ) reagent.

\section{Interpretation of $\mathrm{Ki}-67$ :}

It was evaluated as regard positivity of expression and percentage of expression. The immunoreactivity for Ki-67 was seen as nuclear staining of malignant hepatocytes, where non-tumor liver tissue showed negativity. The assessment of ki-67 was based on nuclear staining pattern. At least 10 fields in each tumor section were evaluated at medium power (200X) to determine the proportion of tumor cells of the entire fields of the sections. The positivity of each staining was also described by means of a Positivity Index (PI), which indicates the percentage of positive cells among 1000 arbitrarily selected tumor cells in a given tissue section. Percentage of positivity was expressed as range, mean and median.

\section{Statistical analysis:}

The data were collected, tabulated and statistically analyzed using the statistical package for the social science program for windows (Version 22; SPSS Inc., Chicago, Illinois, USA). Quantitative data were expressed as mean \pm standard deviation $(\mathrm{X} \pm \mathrm{SD})$ and analyzed by applying Mann-Whitney test (U) for comparison between two groups not normally distributed. Qualitative data were expressed as number and percentage (no \& \%) and 
analyzed by applying chi-square test $\left(\chi^{2}\right)$ and $2 \mathrm{X}$ 2 table, if one cell has expected number less than 5 fisher's exact test was applied.

\section{Results}

The main clinicopathological characteristics of the patients are shown in (Table 1).

Table (1): Distribution of the studied cases according to clinicopathological parameters. $(n=114)$.

\begin{tabular}{|c|c|c|}
\hline Variables & No. & $\%$ \\
\hline \multicolumn{3}{|l|}{ Gender: } \\
\hline Male & 94 & 82.5 \\
\hline Female & 20 & 17.5 \\
\hline \multicolumn{3}{|l|}{ Age (years): } \\
\hline$\leq 60$ & 86 & 75.4 \\
\hline$>60$ & 28 & 24.6 \\
\hline Range & \multicolumn{2}{|c|}{$35.0-75.0$} \\
\hline Mean $\pm \mathrm{SD}$ & \multicolumn{2}{|c|}{$56.25 \pm 7.36$} \\
\hline Median & \multicolumn{2}{|c|}{57.0} \\
\hline HBV (+ve) & 3 & 2.6 \\
\hline $\mathrm{HCV}(+\mathrm{ve})$ & 99 & 86.8 \\
\hline Virology (+ve) & 102 & 89.5 \\
\hline \multicolumn{3}{|l|}{$A F P(n g / m l):$} \\
\hline$<400$ & 76 & 66.7 \\
\hline$\geq 400$ & 18 & 15.8 \\
\hline Censor & 20 & 17.5 \\
\hline Range & \multicolumn{2}{|c|}{$1.0-14500.0$} \\
\hline Mean \pm SD & \multicolumn{2}{|c|}{$683.97 \pm 2278.24$} \\
\hline Median & \multicolumn{2}{|c|}{31.5} \\
\hline \multicolumn{3}{|l|}{ Number of focal lesions: } \\
\hline Single & 83 & 72.8 \\
\hline Multiple & 31 & 27.2 \\
\hline \multicolumn{3}{|l|}{ Size $(\mathrm{cm})$ : } \\
\hline$\leq 5$ & 80 & 70.2 \\
\hline$>5$ & 34 & 29.8 \\
\hline Range & \multicolumn{2}{|c|}{$1.0-17.0$} \\
\hline Mean \pm SD & \multicolumn{2}{|c|}{$5.14 \pm 3.10$} \\
\hline Median & \multicolumn{2}{|c|}{4.0} \\
\hline \multicolumn{3}{|l|}{ Stage (AJCC): } \\
\hline $\mathrm{T} 1$ & 45 & 39.5 \\
\hline $\mathrm{T} 2$ & 58 & 50.9 \\
\hline $\mathrm{T} 3$ & 11 & 9.6 \\
\hline \multicolumn{3}{|l|}{ Type: } \\
\hline Classic & 105 & 92.1 \\
\hline Clear cell & 9 & 7.9 \\
\hline \multicolumn{3}{|l|}{ Grade: } \\
\hline Low grade & 78 & 68.4 \\
\hline High grade & 36 & 31.6 \\
\hline \multicolumn{3}{|l|}{ Differentiation: } \\
\hline Well differentiated & 3 & 2.6 \\
\hline Moderately differentiated & 106 & 93.0 \\
\hline Poorly differentiated & 5 & 4.4 \\
\hline \multicolumn{3}{|l|}{ Adjacent liver: } \\
\hline Non cirrhotic & 21 & 18.4 \\
\hline Cirrhotic & 93 & 81.6 \\
\hline
\end{tabular}

AFP : Alpha Fetoprotein

No : Number.

SD : Standard Deviation.
Immunohistochemical results of $\mathrm{Ki}-67$ in studied cases (Table 2):

Ki-67 immune positive cells were identified by brownish nuclear staining of malignant cells in comparison to negative staining of adjacent nontumorous tissue Figs. $(1,2)$.

Table (2): Immunohistochemical results of Ki-67 in studied cases $(n=114)$.

\begin{tabular}{lll}
\hline Ki-67 & No. & $\%$ \\
\hline Expression: & & \\
Negative & 23 & 20.2 \\
Positive & 91 & 79.8 \\
& & \\
Percentage (\%): & \\
Range & $1.0-95.0$ \\
Mean \pm SD & $42.06 \pm 31.35$ \\
Median & 40.0 \\
No: Number. & \\
SD: Standard Deviation.
\end{tabular}

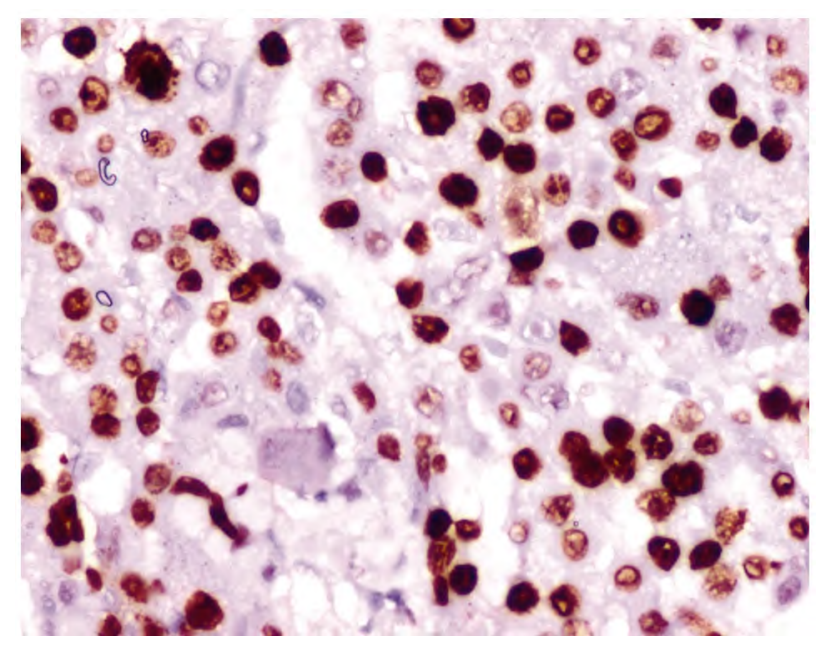

Fig. (1): A case of hepatocellular carcinoma showing positive nuclear Ki-67 expression (IHC X400).

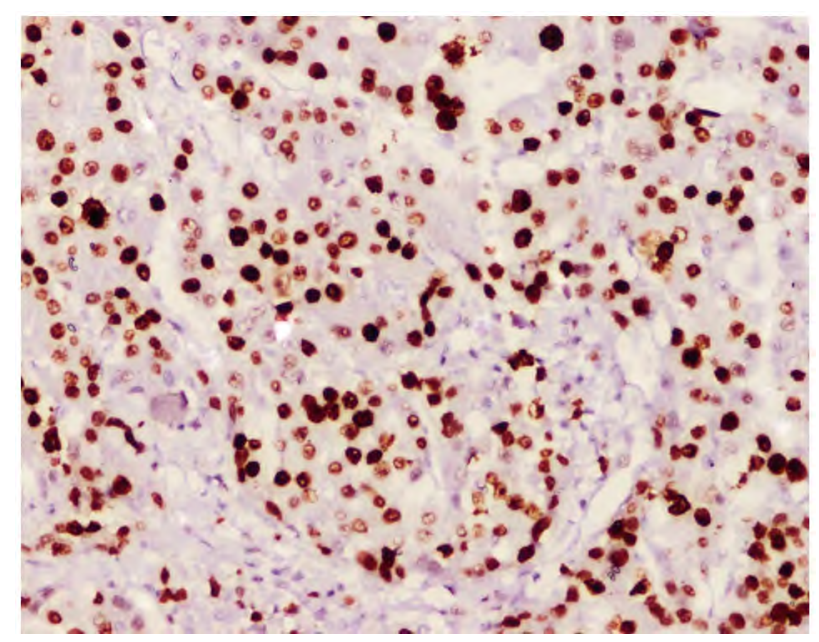

Fig. (2): A case of hepatocellular carcinoma showing high nuclear Ki-67 expression (IHC X200). 
Table (3): Association between Ki-67 (expression) and clinicopathological parameters in total sample $(n=114)$.

\begin{tabular}{|c|c|c|c|c|c|c|}
\hline \multirow{3}{*}{ Variables } & \multicolumn{4}{|c|}{ Ki-67 (expression) } & \multirow{3}{*}{$\begin{array}{c}\text { Test } \\
\text { of sig. }\end{array}$} & \multirow{3}{*}{$\begin{array}{c}p- \\
\text { value }\end{array}$} \\
\hline & \multicolumn{2}{|c|}{$\begin{array}{l}\text { Negative } \\
(\mathrm{n}=23)\end{array}$} & \multicolumn{2}{|c|}{$\begin{array}{l}\text { Positive } \\
(\mathrm{n}=91)\end{array}$} & & \\
\hline & No. & $\%$ & No. & $\%$ & & \\
\hline \multicolumn{7}{|l|}{ Gender: } \\
\hline Male & 18 & 19.1 & 76 & 80.9 & $\chi^{2}=$ & $\mathrm{FE}_{p=}$ \\
\hline Female & 5 & 25.0 & 15 & 75.0 & 0.351 & 0.548 \\
\hline \multicolumn{7}{|l|}{ Age (years): } \\
\hline$\leq 60$ & 19 & 22.1 & 67 & 77.9 & $\chi^{2}=$ & 0.371 \\
\hline$>60$ & 4 & 14.3 & 24 & 85.7 & 0.799 & \\
\hline Range & \multicolumn{2}{|c|}{$35.0-64.0$} & \multicolumn{2}{|c|}{$36.0-75.0$} & & \multirow{3}{*}{0.859} \\
\hline Mean \pm SD & \multicolumn{2}{|l|}{$56.0 \pm 6.42$} & \multicolumn{2}{|c|}{$56.31 \pm 7.62$} & 0.178 & \\
\hline Median & \multicolumn{2}{|l|}{57.0} & \multicolumn{2}{|l|}{57.0} & & \\
\hline \multicolumn{7}{|l|}{$H B V:$} \\
\hline Negative & 23 & 20.7 & 88 & 79.3 & $\chi^{2}=$ & $\mathrm{FE}_{p=}$ \\
\hline Positive & 0 & 0.0 & 3 & 100.0 & 0.799 & 1.000 \\
\hline \multicolumn{7}{|l|}{$\mathrm{HCV}:$} \\
\hline Negative & 1 & 6.7 & 14 & 93.3 & $\chi=$ & $\mathrm{FE}_{p=}$ \\
\hline Positive & 22 & 22.2 & 77 & 77.8 & 1.957 & 0.298 \\
\hline Virology: & & & & & & \\
\hline Negative & 1 & 8.3 & 11 & 91.7 & $\chi^{2}=$ & $\mathrm{FE}_{p=}$ \\
\hline Positive & 22 & 21.6 & 80 & 78.4 & 1.168 & 0.454 \\
\hline$A F P(n g / m l):$ & & & & & & \\
\hline$<400$ & 17 & 22.4 & 59 & 77.6 & $\chi^{2}=$ & $\mathrm{MC}_{p}=$ \\
\hline$\geq 400$ & 5 & 27.8 & 13 & 72.2 & 3.917 & 0.128 \\
\hline Censor & 1 & 5.0 & 19 & 95.0 & & \\
\hline Range & $1.20-4000$ & & $1.0-1$ & 4500.0 & & 0.869 \\
\hline Mean \pm SD & $317.46 \pm 8$ & 47.30 & 795.9 & $6 \pm 2555.77$ & 773.50 & \\
\hline Median & 37.5 & & 27.0 & & & \\
\hline Number: & & & & & & \\
\hline Single & 17 & 20.5 & 66 & 79.5 & $\chi^{2}=$ & 0.894 \\
\hline Multiple & 6 & 19.4 & 25 & 80.6 & 0.018 & \\
\hline Size $(\mathrm{cm})$ : & & & & & & \\
\hline$\leq 5$ & 20 & 25.0 & 60 & 75.0 & $\chi^{2}=$ & $0.049 *$ \\
\hline$>5$ & 3 & 8.8 & 31 & 91.2 & $3.877^{*}$ & \\
\hline Range & $1.0-14.0$ & & $1.0-1$ & 7.0 & $\mathrm{U}=$ & 0.106 \\
\hline Mean \pm SD & $4.26 \pm 2.58$ & & $5.36 \pm$ & $=3.19$ & 820.50 & \\
\hline Median & 4.0 & & 4.0 & & & \\
\hline Stage (AJCC): & & & & & & \\
\hline $\mathrm{T} 1$ & 12 & 26.7 & 33 & 73.3 & $\chi^{2}=$ & 0.312 \\
\hline $\mathrm{T} 2$ & 10 & 17.2 & 48 & 82.8 & 2.327 & \\
\hline $\mathrm{T} 3$ & 1 & 9.1 & 10 & 90.9 & & \\
\hline Type: & & & & & & \\
\hline Classic & 20 & 19.0 & 85 & 81.0 & $\chi^{2}=$ & $\mathrm{FE}_{p=}$ \\
\hline Clear cell & 3 & 33.3 & 6 & 66.7 & 1.050 & 0.383 \\
\hline Grade: & & & & & & \\
\hline Low grade & 16 & 20.5 & 62 & 79.5 & $\chi^{2}=$ & 0.895 \\
\hline High grade & 7 & 19.4 & 29 & 80.6 & 0.017 & \\
\hline Differentiation: & & & & & & $\mathrm{MC}_{n}=$ \\
\hline Moderate & 1 & $\begin{array}{l}33.3 \\
198\end{array}$ & $\begin{array}{l}2 \\
85\end{array}$ & $\begin{array}{l}66.1 \\
802\end{array}$ & $\begin{array}{l}\chi= \\
0955\end{array}$ & 0784 \\
\hline Poor & 1 & 20.0 & 4 & 80.0 & & \\
\hline Adjacent liver: & & & & & & \\
\hline Non cirrhotic & 2 & 9.5 & 19 & 90.5 & $\chi^{2}=$ & $\mathrm{FE}_{p=}$ \\
\hline Cirrhotic & 21 & 22.6 & 72 & 77.4 & 1.813 & 0.237 \\
\hline$\chi^{2}:$ Chi square & test. & & & Number. & & \\
\hline FE : Fisher Exa & & & SD & Standard & Deviation & \\
\hline MC : Monte Car & & & & : Statistic & ly signifi & cant. \\
\hline $\mathrm{U}:$ Mann Whi & iney test. & & AFP & : Alpha Feto & protein. & \\
\hline
\end{tabular}

Table (4): Association between Ki-67 percentage of expression and clinicopathological parameters in total sample $(n=114)$.

\begin{tabular}{|c|c|c|c|c|c|c|}
\hline \multirow{2}{*}{$\begin{array}{l}\text { Clinico- } \\
\text { pathological } \\
\text { parameters }\end{array}$} & \multirow{2}{*}{ No } & \multicolumn{3}{|c|}{ Ki-67 (percentage \%) } & \multirow{2}{*}{$\begin{array}{c}\text { Test } \\
\text { of sig. }\end{array}$} & \multirow{2}{*}{$\begin{array}{c}p- \\
\text { value }\end{array}$} \\
\hline & & Range & Mean \pm SD & Median & & \\
\hline \multicolumn{7}{|l|}{ Age (years): } \\
\hline$\bullet>60$ & 28 & $1.0-95.0$ & $53.57 \pm 32.79$ & 50.0 & 885.50 & \\
\hline \multicolumn{7}{|l|}{ Gender: } \\
\hline -Male & 94 & $2.0-95.0$ & $42.70 \pm 31.51$ & 40.0 & $\mathrm{U}=$ & 0.648 \\
\hline - Female & 20 & $1.0-90.0$ & $39.05 \pm 31.20$ & 45.0 & 879.0 & \\
\hline \multicolumn{7}{|l|}{$H B V:$} \\
\hline - Negative & 111 & $1.0-95.0$ & $42.16 \pm 31.65$ & 40.0 & $\mathrm{U}=$ & 0.979 \\
\hline - Positive & 3 & $20.0-60.0$ & $38.33 \pm 20.21$ & 35.0 & 165.0 & \\
\hline \multicolumn{7}{|l|}{$H C V:$} \\
\hline - Negative & 15 & $2.0-90.0$ & $42.80 \pm 25.04$ & 50.0 & & 0.721 \\
\hline - Positive & 99 & $1.0-95.0$ & $41.95 \pm 32.31$ & 40.0 & 700.0 & \\
\hline \multicolumn{7}{|l|}{ Virology: } \\
\hline - Negative & 12 & $2.0-90.0$ & $43.92 \pm 26.77$ & 50.0 & & 0.684 \\
\hline - Positive & 102 & $1.0-95.0$ & $41.84 \pm 31.95$ & 40.0 & 568.0 & \\
\hline \multicolumn{7}{|l|}{$A F P(n g / m l):$} \\
\hline$\bullet<400$ & 76 & $1.0-95.0$ & $44.32 \pm 32.74$ & 50.0 & $\mathrm{~K}=$ & 0.442 \\
\hline$\bullet \geq 400$ & 18 & $2.0-95.0$ & $33.06 \pm 31.26$ & 20.0 & 1.633 & \\
\hline - Censor & 20 & $2.0-90.0$ & $41.60 \pm 25.33$ & 42.50 & & \\
\hline \multicolumn{7}{|l|}{ Number: } \\
\hline - Single & 83 & $1.0-95.0$ & $39.88 \pm 31.44$ & 40.0 & $\mathrm{U}=$ & 0.292 \\
\hline - Multiple & 31 & $2.0-95.0$ & $47.90 \pm 30.86$ & 50.0 & 1121.5 & \\
\hline \multicolumn{7}{|l|}{ Size $(\mathrm{cm})$ : } \\
\hline$\bullet \leq 5$ & 80 & $1.0-95.0$ & $37.10 \pm 29.82$ & 40.0 & $\mathrm{U}=$ & $0.015^{*}$ \\
\hline$\bullet>5$ & 34 & $2.0-95.0$ & $53.74 \pm 32.19$ & 50.0 & 968.50 & \\
\hline \multicolumn{7}{|l|}{ Stage (AJCC): } \\
\hline - T1 & 45 & $1.0-95.0$ & $33.26 \pm 26.83$ & 25.0 & $\mathrm{~K}=$ & 0.054 \\
\hline - $\mathrm{T} 2$ & 58 & $2.0-95.0$ & $46.56 \pm 33.72$ & 47.0 & 5.767 & \\
\hline$\bullet \mathrm{T} 3$ & 11 & $2.0-95.0$ & $54.27 \pm 28.68$ & 50.0 & & \\
\hline \multicolumn{7}{|l|}{ Type: } \\
\hline - Classic & 105 & $1.0-95.0$ & $43.34 \pm 31.46$ & 50.0 & $\mathrm{U}=$ & 0.093 \\
\hline - Clear cell & 9 & $2.0-80.0$ & $27.11 \pm 27.25$ & 20.0 & 313.0 & \\
\hline \multicolumn{7}{|l|}{ Grade: } \\
\hline - Low grade & 78 & $1.0-95.0$ & $43.51 \pm 29.94$ & 50.0 & & 0.488 \\
\hline - High grade & 36 & $2.0-95.0$ & $38.92 \pm 34.44$ & 20.0 & 1290.5 & \\
\hline \multicolumn{7}{|l|}{$\begin{array}{l}\text { Differentia- } \\
\text { tion: }\end{array}$} \\
\hline $\begin{array}{l}\text { - Well differ- } \\
\text { entiated }\end{array}$ & 3 & $5.0-60.0$ & $38.33 \pm 29.29$ & 50.0 & $\begin{array}{l}\mathrm{K}= \\
0.162\end{array}$ & 0.922 \\
\hline $\begin{array}{l}\text { - Moderately } \\
\text { differentiated }\end{array}$ & 106 & $1.0-95.0$ & $42.0 \pm 31.24$ & 40.0 & & \\
\hline $\begin{array}{l}\text { - Poorly differ- } \\
\text { entiated }\end{array}$ & 5 & $8.0-95.0$ & $45.60 \pm 40.97$ & 20.0 & & \\
\hline \multicolumn{7}{|l|}{ Adjacent liver: } \\
\hline - Non-cirrhotic & & $2.0-95.0$ & $47.33 \pm 30.70$ & 5.0 & $\mathrm{U}=$ & 0.342 \\
\hline - Cirrhotic & 93 & $1.0-95.0$ & $40.87 \pm 31.53$ & 40.0 & 847.0 & \\
\hline
\end{tabular}

$\mathrm{K}: \mathrm{K}$ for Kruskal Wallis test. $\quad * \quad$ : Statistically significant

U : Mann Whitney test. AFP : Alpha Fetoprotein.

SD : Standard Deviation. No : Number.

\#: Excluded from the association due to small number of case $(n=1)$.

Ki-67 was expressed in 91 cases of the studied group with a percentage of $79.8 \%$.

The percentage of Ki-67 expression ranged between 1 and 95 with a mean \pm SD of $56.72 \pm 40.53$ and a median of 80 . 
Association between Ki-67 expression and different clinicopathological parameters (Table 3). There was statistically significant association between large tumor size $(>5 \mathrm{~cm})$ and positive Ki-67 expression ( $p$-value $=0.049)$. Also, there was statistically significant association between high percentage of expression and old age group ( $>60$ years $)(p$-value $=0.035)$ and advanced tumor stage (T3) $(p$-value $=0.054)$.

Correlation between Ki-67 percentage of expression and different clinicopathological parameters (Tables 4,5):

There was direct correlation between Ki-67 percentage of expression and both age and size of the tumor $(p$-value $=0.035$ and 0.021$)$ respectively.

Table (5): Correlation between Ki-67 percentage of expression and different clinicopathological parameters in total sample $(n=114)$.

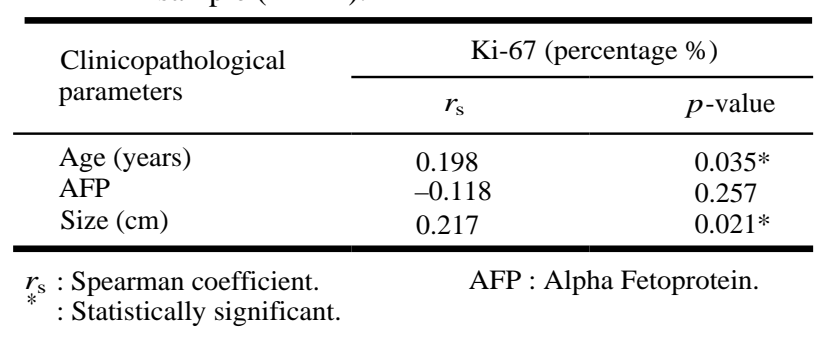

\section{Discussion}

Hepatocellular Carcinoma (HCC) is the sixth most common malignancy and is the leading cause of mortality in patients with cirrhosis [1,2]. Ki-67 is a direct substrate of the cyclin-dependent kinase CDK1 and is hyperphosphorylated in mitosis $[7,8]$ Studies showed that the proliferative activity of a wide variety of tumors may be of prognostic value with respect to survival of the patient. Current methods to assess the proliferation and growth of tumors includes immunohistochemical staining of Ki-67 [9].

In hepatocellular carcinoma, $\mathrm{Ki}-67$ has been used as a useful proliferative marker in several studies [17].

Besides, there have been already studies demonstrating that Ki-67 was strongly associated with the aggressiveness of tumor, including prostatic cancer [13]. In addition, several meta-analyses concluded that high Ki-67 could predict poor prognosis in patients with cervical cancer, gliomas, lymphoma, breast cancer, and lung cancer $[\mathbf{1 3 , 1 8 -}$ 22]. It was reported that $\mathrm{Ki}-67$ could be an independent marker for worse prognosis in patients with liver cancer, those results were contradictory [13,23-27]
In the present study, the expressions of the proliferative marker Ki-67 114 cases. Ki-67 was expressed in 91 cases of the studied group with a percentage of $79.8 \%$.

The percentage of Ki-67 expression ranged between 1 and $95 \%$ with a mean \pm SD of $56.72 \pm$ 40.53 and a median of 80 . Ki-67 was highly expressed and significantly related to large tumor size, older age and advanced tumor stage.

The present study matched with a meta-analysis provided evidence that high Ki-67 was closely associated with large tumor size [7]. However, this meta-analysis showed close association between $\mathrm{Ki}-67$ and histological grade, number of tumor nodes, the status of metastasis, cirrhosis and vein invasion in HCC patients in contrast to the results in the present study [7].

Other studies showed that the expression of $\mathrm{Ki}-67$ has been found to correlate with the histological stages of hepatocellular carcinoma in agreement to the present study $[13,18,20]$ and tumor progression [13,22].

Mohamed et al., and others $[\mathbf{5 , 2 8 , 2 9 ]}$ found that the expressions of the proliferative marker Ki-67 was highly expressed and significantly related to the tumor grade, portal invasion and intra-hepatic metastasis. None of these results matched with our study. This discrepancy in results could be due to the difference in the sensitivity of the monoclonal antibodies used.

$\mathrm{Ng}$ et al., [22] in their study found strong association between $\mathrm{Ki}-67$ expression and tumor cellular differentiation. We failed to find a significant correlation between Ki-67 expression and other pathologic features, such as tumor invasiveness in terms of venous permeation and direct liver invasion. These results were comparable to $\mathrm{Ng}$ et al., results [22]. In contrast, tumor size in their study [22] had no correlation to Ki-67 expression.

\section{Conclusion:}

$\mathrm{Ki}-67$ expression is associated with aggressiveness of HCC as it I associated with poor prognostic parameters such as older age, larger tumor size and higher tumor stage (T3).

\section{References}

1- WAGHRAY A., MURALI A.R. and MENON K.N.: Hepatocellular carcinoma: From diagnosis to treatment. World J. Hepatol., May 18; 7 (8): 1020-9, 2015.

2- ALAZAWI W.1., CUNNINGHAM M., DEARDEN J. and FOSTER G.R.: Systematic review: Outcome of compen- 
sated cirrhosis due to chronic hepatitis $\mathrm{C}$ infection. Aliment Pharmacol Ther., Aug., 32 (3): 344-55, 2010.

3- American Cancer Society: Cancer Facts and Figures 2014. Atlanta, Ga: American Cancer Society, 2014.

4- World Health Organization IAfRoC. GLOBOCAN 2012.

5- MOHAMED W.S.1., OMAR M.M., KHAYRI T.M. and FAKHR I.M.: Assessment of the Proliferative Marker Ki67 and p53 Protein Expression in HBV-and HCV-related Hepatocellular Carcinoma Cases in Egypt. Int. J. Health Sci. (Qassim). Jan., 2 (1): 27-34, 2008.

6- ZHANG X., ZHANG H. and YE L.: Effects of hepatitis $B$ virus $X$ protein on the development of liver cancer. J. Lab. Clin. Med., Feb., 147 (2): 58-66, 2006.

7- SOBECKI M., MROUJ K., CAMASSES A., PARISIS N., NICOLAS E., LLÈRES D., GERBE F., PRIETO S., KRASINSKA L., DAVID A., EGUREN M., BIRLING M.C., URBACH S., HEM S., DÉJARDIN J., MALUMBRES M., JAY P., DULIC V., LAFONTAINE D.L.J., FEIL R. and FISHER D.: The cell proliferation antigen Ki-67 organises heterochromatin. Elife, Mar. 7, 5: e13722, 2016.

8- GERDES J., LI L., SCHLUETER C., DUCHROW M., WOHLENBERG C., GERLACH C., STAHMER I., KLOTH S., BRANDT E. and FLAD H.D.: Immunobiochemical and molecular biologic characterization of the cell proliferation-associated nuclear antigen that is defined by monoclonal antibody Ki-67. The American Journal of Pathology, 138: 867-73, 1991.

9- KING K.L., HWANG J.J., CHAU G.Y., TSAY S.H., CHI C.W., LEE T.G., WU L.H., WU C.W. and LUI W.Y.: Ki67 expression as a prognostic marker in patients with hepatocellular carcinoma. J. Gastroenterol. Hepatol., Mar., 13 (3): 273-9, 1998.

10- GERDES J., SCHWAB U., LEMKE H. and STEIN H.: Production of a mouse monoclonal antibody reactive with a human nuclear antigen associated with cell proliferation. International Journal of Cancer, 31: 13-20, 1983.

11- SCHMIDT M.H., BROLL R., BRUCH H.P., BÖGLER $\mathrm{O}$. and DUCHROW M.: The proliferation marker $\mathrm{pKi}$ 67 organizes the nucleolus during the cell cycle depending on Ran and cyclin B. The Journal of Pathology, 199: 1827, 2003.

12- BOOTH D.G., TAKAGI M., SANCHEZ-PULIDO L., PETFALSKI E., VARGIU G., SAMEJIMA K., IMAMOTO N., PONTING C.P., TOLLERVEY D., EARNSHAW W.C. and VAGNARELLI P.: Ki-67 is a PP1-interacting protein that organises the mitotic chromosome periphery. eLife, 3: e13722, 2014.

13- LYNCH D.A.1., CLARKE A.M., JACKSON P., AXON A.T., DIXON M.F. and QUIRKE P.: Comparison of labelling by bromodeoxyuridine, MIB-1, and proliferating cell nuclear antigen in gastric mucosal biopsy specimens. J. Clin. Pathol., Feb., 47 (2): 122-5, 1994.

14- LUO Y.1., REN F. 1., LIU Y.1., SHI Z.1., TAN Z.1., XIONG H. 1., DANG Y.1. and CHEN G. 1.: Clinicopathological and prognostic significance of high Ki-67 labeling index in hepatocellular carcinoma patients: A metaanalysis. Int. J. Clin. Exp. Med., Jul. 15, 8 (7): 10235 47, 2015.
15- ABD EL-RAHMAN M.H.1., PILARSKI R., CEBULLA C.M., MASSENGILL J.B., CHRISTOPHER B.N., BORU G., HOVLAND P. and DAVIDORF F.H.: Germline BAP1 mutation predisposes to uveal melanoma, lung adenocarcinoma, meningioma, and other cancers. J. Med. Genet., Dec., 48 (12): 856-9, 2011.

16- GILTNANE J.M. and RIMM D.L.: Technology insight: Identification of biomarkers with tissue microarray technology. Nat. Clin. Pract. Oncol., Dec., 1 (2): 104-11, 2004.

17- WU P.C.1., FANG J.W., LAU V.K., LAI C.L., LO C.K. and LAU J.Y.: Classification of hepatocellular carcinoma according to hepatocellular and biliary differentiation markers. Clinical and biological implications. Am. J. Pathol., Oct., 149 (4): 1167-75, 1996.

18-NAGAO T. 1., ISHIDA Y. and KONDO Y.: Determination of S-phase cells by in situ hybridization for histone $\mathrm{H} 3$ mRNA in hepatocellular carcinoma: Correlation with histologic grade and other cell proliferative markers. Mod. Pathol., Feb., 9 (2): 99-104, 1996.

19-FACCIOLI S. 1., CHIECO P., GRAMANTIERI L., STECCA B.A. and BOLONDI L.: Cytometric measurement of cell proliferation in echo-guided biopsies from focal lesions of the liver. Mod. Pathol., Feb., 9 (2): 120-5, 1996.

20- SHIRABE K.1., KITAMURA M., TSUTSUI S., MAEDA T., MATSUMATA T. and SUGIMACHI K.: A long-term survivor of ruptured hepatocellular carcinoma after hepatic resection. J. Gastroenterol. Hepatol., May-Jun., 10 (3): 351-4, 1995.

21- MAEDA T.1., TAKENAKA K., ADACHI E., MATSUMATA T., SHIRABE K., HONDA H., SUGIMACHI K. and TSUNEYOSHI M.: Small hepatocellular carcinoma of single nodular type: A specific reference to its surrounding cancerous area undetected radiologically and macroscopically. J. Surg. Oncol., Oct., 60 (2): 75-9, 1995.

22- NG I.O., NA J., LAI E.C., FAN S.T. and NG M.: Ki-67 antigen expression in hepatocellular carcinoma using monoclonal antibody MIB 1 . A comparison with proliferating cell nuclear antigen. Am. J. Clin. Pathol., Sep., 104 (3): 313-8, 1995.

23- THAN K.W.1., OKAYASU I. and AKASHI T.: Histopathological and immunohistochemical analysis of adenomatous hyperplasia and hepatocellular carcinoma: Cellularity, thickness of cell cord, and Ki-67 proliferative activity. Bull Tokyo Med. Dent. Univ., Jun., 42 (2): 67-81, 1995.

24- MARTIN B., PAESMANS M., MASCAUX C., BERGHMANS T., LOTHAIRE P., MEERT A.P., LAFITTE J.J. and SCULIER J.P.: Ki-67 expression and patients survival in lung cancer: Systematic review of the literature with meta-analysis. Br. J. Cancer, 91: 2018-25, 2004.

25- De AZAMBUJA E., CARDOSO F., De CASTRO G. Jr., COLOZZA M., MANO M.S., DURBECQ V., SOTIRIOU C., LARSIMONT D., PICCART-GEBHART M.J. and PAESMANS M.: Ki-67 as prognostic marker in early breast cancer: A meta-analysis of published studies involving 12,155 patients. Br. J. Cancer, 96: 1504-13, 2007.

26- HE X., CHEN Z., FU T., JIN X., YU T., LIANG Y., ZHAO $\mathrm{X}$. and HUANG L.: Ki-67 is a valuable prognostic predictor of lymphoma but its utility varies in lymphoma 
subtypes: Evidence from a systematic meta-analysis. BMC Cancer, 14: 153, 2014.

27- CHEN W.J., HE D.S., TANG R.X., REN F.H. and CHEN G.: $\mathrm{Ki}-67$ is a valuable prognostic factor in gliomas: Evidence from a systematic review and meta-analysis. Asian Pac. J. Cancer Prev., 16: 411-20, 2015.

28- PAN D., WEI K., LING Y., SU S., ZHU M. and CHEN
G.: The Prognostic Role of Ki-67/MIB-1 in Cervical Cancer: A Systematic Review with Meta-Analysis. Med. Sci. Monit., 21: 882-9, 2015.

29- STROESCU C., DRAGNEA A., IVANOV B., PECHIANU C., HERLEA V., SGARBURA O., POPESCU A. and POPESCU I.: Expression of p53, Bcl-2, VEGF, Ki-67 and PCNA and prognostic significance in hepatocellular carcinoma. J. Gastrointestin. Liver Dis., 17: 411-7, 2008.

\section{الإرتباط بين التعبير عن كاى TV وعدوانية سرطان الخلايا الكبدية}

$$
\begin{aligned}
& \text { الخلفية: كاى TV هو دليل تكاثر نوقى ولذلك يستخدم على نطاق واسع كدليل تكاثر خلوى لتصديد درجة الآورام. } \\
& \text { الهدف من الدراسة: هو تقييم الإرتباط الحتمل ما بين كاى TV وعلوانية سرطان الخلايا الكبدية. }
\end{aligned}
$$

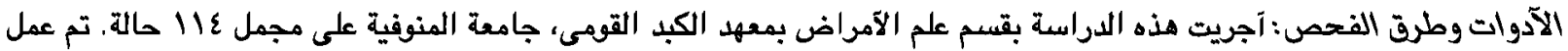

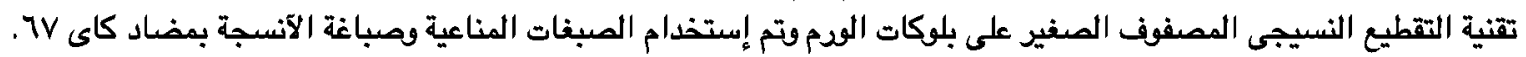

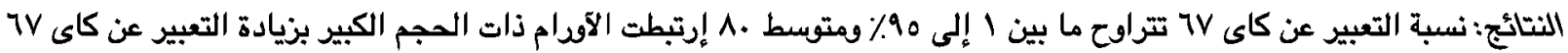

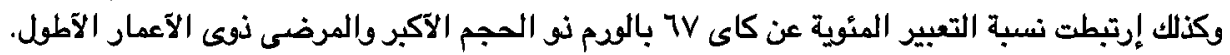

$$
\begin{aligned}
& \text { الخلاصة: التعبير عن كاى VV يرتبط بعدوانية سرطان الخلايا الكبدية ومن ثم يمكن تغيير نوعية العلاج لهذه الآتدام. }
\end{aligned}
$$

